\title{
A Comparison of the Multiple Intelligence Profiles of Trainee Music Teachers in Respect of Music Genre Preference
}

\author{
Yuksel Pirgon $^{1}$ \\ ${ }^{1}$ Music Department, Fine Arts Faculty, Suleyman Demirel University, Isparta, Turkey \\ Correspondence: Yuksel Pirgon, Music Department, Fine Arts Faculty, Suleyman Demirel University, Isparta, \\ Turkey. E-mail: ypirgon@hotmail.com
}

Received: January 16, 2021

Accepted: April 19, 2021

Online Published: June 24, 2021

doi:10.5539/ies.v14n7p36

URL: https://doi.org/10.5539/ies.v14n7p36

\begin{abstract}
The aim of this study was to compare the multiple intelligence profiles of students in the Music Education Department of Necmettin Erbakan University, Ahmet Kelesoglu Faculty of Education, Department of Music Teaching of Fine Arts Department, in relation to the variable of music genre to which they preferred to listen. The data collection tool used in the research was the 80-item "Scale for the Evaluation of Multiple Intelligence Areas", developed by Armstrong, and to obtain the relevant variables, a structured interview form was prepared. The scale was applied to 106 trainee music teachers. Conformity of the data obtained to normal distribution was assessed with the Kolmogorov-Smirnov test, and in the comparisons of multiple groups, the One Way ANOVA test was applied as the data showed normal distribution. The most general result that emerged was that there was a difference between the points of the multiple intelligence profiles that the students have developed according to the music genre to which they listen. A striking result was that there was a significant difference between all the intelligence profile points of the students who preferred to listen to rap/hip-hop music and those of the students who preferred other music types.
\end{abstract}

Keywords: trainee music teacher, intelligence, multiple intelligence profiles, music genre

\section{Introduction}

For many years intelligence has been one of the most researched fundamental topics in the field of Psychology and Educational science. Therefore, many different studies have been conducted and different theories have been developed. Intelligence can be defined as a capacity; a capacity for adaptability, for learning and for recognizing relationships between things. Since the beginning of the last century, the nature of intelligence, its origins and the question of how it should be measured have been debated (Özden, 2014). To the question of what are the indicators of the intelligence of an individual, the most common responses are the abilities in problem-solving, use of logic, and critical-thinking. This traditional approach in the past gave rise to the idea that to create appropriate educational environments, it was necessary to identify the abilities of individuals and separate them into classes accordingly. After the Parisian educator, Alfred Binet, developed the Intelligence Quotient (IQ) test, which can measure the intelligence level of a child, students could be classified as high or low intelligence and on the basis of these levels, gifted and special education classes were formed (Talu, 1999).

The IQ scale is still in current use for the measurement of cognitive intelligence. The scores obtained from the WISC-R Test, one of the most commmonly-used tests employing the IQ scale, are regarded as important for various purposes (Köksal \& Boran, 2015). According to classical IQ theory, intelligence is a single and constant determinant. Tests performed at school are based on a limited concept of intelligence, which is disconnected from the actual skills and abililties in life that extend far beyond these limitations (Goleman, trans. Özden, 2014). While previously, only competence in mathematical and verbal areas were accepted as intelligence, a definition of multiple intelligence began to gain ground in which intelligence was not reduced to a binary concept but was recognised as encompassing different areas (Özden, 2014).

\section{Literature Review}

The literature review consists of the following concepts and theories.

\subsection{The Concept of intelligence and the Theory of Multiple Intelligence}

The acceptance of special abilities, as well as general abilities, required a re-defintion of intelligence. Intelligence 
has been defined in many different ways by educational psychologists. Accordingly, sometimes it has been thought of as the points obtained in an intelligence test, sometimes as the capacity to adapt to circumstances, and sometimes as problem-solving ability (Azar, 2006). It is clear that measuring intelligence has always been a somewhat controversial endeavour. Moreover, the varying personality traits of individuals, as well as differences in their emotional and intellectual make-up, mean that even standardized intelligence tests can be misleading. (Aydın, 2005). Within the framework of this understanding, the Theory of Multiple Intelligences was introduced by Howard Gardener in the book "Frames of mind: The Theory of Multiple Intelligences", published in 1983. According to this theory, intelligence is not linked to a single concrete factor which can be tested with quantative data. Intelligence is not a fixed, uniform concept unable to change or develop; on the contrary, it is a multi-type individual formation affected by social structure which may be subject to change and development. It is wrong to regard an individual's intelligence as being completely hereditary and therefore fixed since birth. Each individual is different, unique, and has their own specific potential as a human being. One of the most important resposibilities of humankind is to discover his or her uniqueness and potential for growth and development (Tuğrul \& Duran, 2003).

In the Gardner theory, it is explained that people have 8 different intelligence profiles. Examples of these profiles are found in every individual, which are felt when one or more is predominant, but nonetheless, intelligence is seen in each person as a different combination or mixture of these eight profiles. Although genetic factors are effective in the formation and development of intelligence, the maintenance of this is also affected by environmental factors and sociocultural elements.

The multiple intelligence profiles defined by Gardner are separated into the following categories:

1) Verbal-linguistic intelligence: The ability to use language effectively both verbally and in writing. Individuals with a high linguistic intelligence learn primarily by reading, discussing and listening. People with high verbal-linguistic intelligence think in terms of concepts and words. High linguistic intelligence is seen in writers, some politicians, and scientists.

2) Musical intelligence: This is a sensitivity to the basic components of music (eg. melody, rhythm, tempo, intensity of sound, harmony, music forms), the ability to play an instrument, to sing, or compose musical pieces (songs, folk ballads, symphonies, concertos, etc.). Those with high musical intelligence think in terms of rhythms, melodies and sounds. People with high musical intelligence enjoy singing and playing an instrument.

3) Logical-mathematical intelligence: The ability to reason and use numbers effectively. People with high logical-mathematical intelligence learn by classifying, ordering, and abstracting. They are relational thinkers, who reason and question, and try to determine cause and effect relationships. People with high logical-mathematical intelligence enjoy problem-solving, asking questions, and logical thinking. High logical-mathematical intelligence is seen in researchers, scientists, and philosophers.

4) Spatial-visual intelligence: This is sensitivity to form, shape, space, colour, and lines. Individuals with high visual intelligence think by means of imagination and visualization. People with high spatial-visual intelligence love colour and learn through colour and pictures. They keep geographical locations and directions in mind and benefit from this information. Spatial-visual intelligence type is seen in artists, sculptors, and architects.

5) Bodily-kinesthetic intelligence: This is the ability to solve problems and use the body to express thoughts and feelings. Those with high bodily intelligence learn by touching, tasting, and smelling. People with high bodily-kinesthetic intelligence are active and learn better by doing and experiencing things first hand. High bodily intelligence is seen in dancers and sports people.

6) Intrapersonal intelligence: This is the ability to understand one's strengths and weaknesses, moods, desires and intentions, and to therefore be able to lead a more effective life. Individuals with high intrapersonal intelligence learn alone, with individual projects, and at their own pace. Intrapersonal thinkers learn by relating topics to themselves and integrating them into their own method of thinking. These individuals tend towards the pursuit of meaningful and productive goals to enrich their existence. This type of intelligence is seen more in poets, literary writers, and artists.

7) Interpersonal intelligence: This is the ability to sense the temperament, emotions, motives and intentions of others, to understand how to interact and work with others and to be able to solve interpersonal problems. These individuals learn better through teamwork and collaboration. People with high interpersonal intelligence want to know how others understand in order to build their own understanding. They learn best by relating subjects to real life. High interpersonal intelligence is seen in psychotherapists, teachers, marketing people, and politicians.

8) Naturalist intelligence: This is the ability to observe nature and what is happening in nature. People with high 
naturalist intelligence learn primarily through research, observation and examination. When speaking, they frequently make reference to nature (Gardner, 2004; Aydın, 2005; Özden, 2014).

Current theories of intelligence combine the basic biological points and the idea that intelligence is both a capacity or potential. It is regarded as a combination of congenital and inherited traits, including the functions of the central nervous system, shaped by experience, learning and environmental factors (Çuhadar, 2017).

\subsection{Factors Influencing Musical Preference}

The factors affecting the musical preferences of an individual can be said to include age, gender, intelligence, personality, ethnicity, sociocultural and socio-economic group status, geographical location, life experience, and level of education. When these factors are examined as a whole, musical preference can be predicted to be a form of preference able to be developed, changed and differentiated depending on change in the aforementioned factors.

\subsubsection{Musical Preference Based on Personality Factors}

In a study by Rentfrow and Gosling (2003), musical preferences were classified in four distinct categories and specific personality traits were listed within each category. The music genres related to these categories were as follows; the contemplative-complex category included jazz music, blues music, classical music, and folk music; the intense-rebellious category included alternative music, rock music, and heavy metal music; the cheerful-traditional category included country music, pop music, religious music, and film soundtracks; and the energetic-rhythmic category included rap/hip-hop music, soul/funk music, and electronic/dance music. It was observed that those with musical preferences in the intense-rebellious category enjoyed taking risks, were physically active and had enquiring minds. Those who listened to energetic-cheerful music were seen to be cheerful, trustworthy and sociable, enjoyed helping others, and considered themselves attractive. Those who listened to energetic-rhythmic music were chatty, vivacious, and forgiving individuals, who also regarded themselves as attractive. Those listening to contemplative-complex music were seen to be open to new experiences who regard themselves as clever and, while they were determined to be individuals with strong verbal skills there was a negative correlation with athletic ability.

\subsubsection{Music Preference Based on Age and Gender}

Hargreaves and O'Neill (1998) reported that during adolescence, boys tended to listen to music to impress friends, whereas girls tended to listen to music to fulfill an emotional need and express their feelings (as cited in North \& Hargreaves, 2008). In studies by LeBlanc et al. (1996), 2262 participants between 6 and 91 years of age were asked to state their preferences after listening to 18 sample pieces of music comprising western music, jazz music, and rock music. The results obtained showed that high school students had more varying preferences than middle-school students, and they were more insistent in their preferences, and adults were more decisive in their preferences than the younger participants. Therefore, it can be said that musical preferences become more consistent with age.

\subsubsection{Musical Preference Based on Socio-Cultural/Economic Factors}

Music is always heard in a social context, at a specific time or place, together with other people or alone and combined with other activities which have their own complex meaning and emotional source (Konecni, 1982). Variables such as personal characteristics, environment, life experience and socio-economic status affect the musical preferences of an individual. It is the person with their culture and social environment that provides a constantly developing and updating living concept of music genres (Demirtaş \& Köse 2018). Important social factors determining musical preference include social class, family, peers, culture, media, and the prestige effect. Most researchers have stated that the most important factor affecting taste in music is the social context in which the music is found. Although the structural features of music and the importance of other listening conditions are undeniable, the meaning and importance of music for people cannot be understood without considering the effect of social conditions (Şenel, 2014).

According to Russell (1997), there are two different views of the relationship between social structure and musical taste. In the first view, differences in musical taste are a product of social stratification, while in the second, musical taste is one of several factors defining social stratification. Russell reported that both views were partially true, as social structure and musical taste had a mutual effect on each other. For example, the separation of different music genres which shape cultures, most likely emerged as a response to the need to differentiate different social groups.

\subsubsection{Musical Preferences Based on Educational Factors}

In studies by Hargreaves, Comber and Colley (1995), it was concluded that there was a correlation between 
musical preference and music education. Kenston and Pinto (1955) and Geringer (1982) researched how music education affected musical preference. It was observed that classical music was preferred more by participants with at least one year of music education compared to those with no musical education. In another study of 278 participants, Hargreaves, Comber and Colley (1995) determined that there were significant links between music education and musical preference.

\subsubsection{Musical Preference Based on Intellect}

Finally, it is fitting to refer to the fundamental subject of this study, which is the influence of intelligence on musical preference. The perception, interpretation, and investigation of a harmonious sound structure, down to the finest detail by the brain, is undoubtedly one of the most important components of intelligence.

Hearing and music are very closely related. First, the presence of a vibrating object is necessary to hear music or sound. Next, the ear has to detect and transmit the vibration. Perception and interpretation by the brain of the sound coming to the ear are prerequisites to hear music (Çuhadar, 2017). The perception and judgement of organized sounds by the brain is related to intelligence as it involves analysis, interpretation and reasoning skills. More cognitively complex individuals have been found to have more complex preferences whilst less cognitively complex individuals have been found to have less complex preferences (Kaçmaz, 2017). According to Rentfrow and Gosling (2003), an active imagination, a variety of aesthetic experiences and a tendency to view themselves as intellectuals were all traits which could be observed in people preferring reflective and complex music such as classical or jazz .

Within the framework of these explanations, it may be considered that students studying at an institution providing music education is not indicative of only musical intelligence of the multiple intelligence profiles being developed. As Gardner stated, an individual uses a combination of these 8 intelligence profiles throughout their education, although the dominant types vary between individuals. From this starting point, it is important to understand the distribution of intelligence profiles within music preferences and try to ascertain the dominant type of intelligence profile based on the clues provided by the genre of music to which they listen. When these clues are combined with other acquired approaches, it will provide information about the student's dominant intelligence profiles, which in turn, will allow for the most appropriate approaches and methods to be used in their education. It is known that a single approach in education is not an efficient method for every student. For this purpose, the theory of multiple intelligence has been proposed for the consideration of new educational methods. In studies of schools, Gardner observed that only two types of intelligence (Verbal-linguistic intelligence, and Logical-mathematical intelligence) were being used whilst the other types were used solely outside of school (Talu, 1999). An educational approach based on the students' intelligence profiles will increase the efficiency of the educational programme in successfully achieving targets.

Within the framework of this information, the answers to the following questions were sought in this research;

1) What are the developed/highly developed intelligence profiles of the students?

2) What other developed/highly developed intelligence profiles are found in students with a highly developed musical intelligence profile.

3) What are the results of comparing the multiple intelligence profiles of students with the variable of their music preferences.

\section{Methodology}

As a quantitative research method, the causal comparison method was used to compare the multiple intelligence profiles of the students according to the variable of their preferred music genres. Causal comparison studies are a type of research aimed at determining the causes of an existing/naturally occurring situation or event and the variables affecting these causes or the results of an effect (Büyüköztürk et al., 2008). Especially in social sciences, not being able to provide the controls required by experimental models for each problem, economic reasons, or that situations may form contrary to value judgments make it necessary to use comparative models more (Karasar, 2008).

\subsection{Research Group}

The study included a total of 106 students comprising 75 females and 31 males, selected with the random sampling method from those studying in the Music Education Department of Necmettin Erbakan University, Ahmet Kelesoglu Faculty of Education, Department of Music Teaching of Fine Arts Department. 


\subsection{Data Collection Tools}

\subsubsection{Multiple Intelligence Areas Evaluation Scale}

Developed by Armstrong in 1994, this scale was translated into Turkish by Özden 1997 and validity and reliability were calculated. The scale consists of 80 items with 5-point Likert type responses of "not at all appropriate", "slightly appropriate", "partially appropriate", "quite appropriate" and "entirely appropriate", scored from 0-4, respectively. Distribution of the scale items according to intelligence areas is shown in Table 1.

Table 1. Distribution of the scale items according to intelligence areas

\begin{tabular}{lc}
\hline Intelligence areas & Distribution of the scale items \\
\hline Verbal-linguistic intelligence & $1,9,17,25,33,41,49,57,65,73$ \\
Logical-mathematical intelligence & $2,10,18,26,34,42,50,58,66,74$ \\
Spatial-visual intelligence & $3,11,19,27,35,43,51,59,67,75$ \\
Bodily-kinesthetic intelligence & $4,12,20,28,36,44,52,60,68,76$ \\
Naturalist intelligence & $5,13,21,28,37,45,53,61,69,77$ \\
Musical intelligence & $6,14,22,30,38,46,54,62,70,78$ \\
Interpersonal intelligence & $7,15,23,31,39,47,55,63,71,79$ \\
Intrapersonal Intelligence & $8,16,24,32,40,48,56,64,72,80$ \\
\hline
\end{tabular}

Points obtained in the scale are shown in Table 2.

Table 2. Points corresponding to the development status of the intelligence area

\begin{tabular}{lc}
\hline Development status of the area of intelligence & Corresponding points \\
\hline Undeveloped & $0-10$ \\
Slight & $11-20$ \\
Average & $21-30$ \\
Developed & $31-40$ \\
Highly developed & $41-50$ \\
\hline
\end{tabular}

\subsubsection{Interview Form}

A structured interview form was prepared by the researcher to obtain the variables to be investigated in the study. In this form students were asked to select only one of 5 options regarding their preferred music genre. These 5 options were; traditional music, rap/hip-hop music, western classical music, popular music, and rock/heavy metal music.

\subsection{Data Analysis}

Data obtained in the study were analyzed statistcally using SPSS vn 22.0 software. Conformity of the data to normal distribution was assessed using the One-Sample Kolmogorov-Smirnov Test, and normal distribution was seen as the skewness and kurtosis values of the results were between -1.5 and 1.5. Therefore, parametric tests were applied in the analysis of the data. Due to the use of multiple groups in the comparison of multiple intelligence profiles according to the variable of music preference, the One Way ANOVA test was used. The source of difference in multiple groups was analysed using the Tukey test.

\section{Results}

The findings of the research questions outlined in this section are presented by grouping each research question as a separate finding item.

\subsection{Percentage Distribution of the Developed/Highly Developed Intelligence Profiles of the Students}

The percentage frequency distributions of "developed" and "highly developed" intelligence profiles of students who participated in the study are presented in Table 3. 
Table 3. Percentage frequency values of the developed/highly developed intelligence profiles of the students

\begin{tabular}{lcc}
\hline Multiple intelligence profiles & $\%$ & $\mathrm{f}$ \\
\hline Verbal-linguistic intelligence & 71.7 & 76 \\
Logical-mathematical intelligence & 71.7 & 76 \\
Spatial-visual intelligence & 76.4 & 81 \\
Bodily-kinesthetic intelligence & 78.3 & 95 \\
Naturalist intelligence & 80.2 & 83 \\
Musical intelligence & 89.6 & 73 \\
Interpersonal intelligence & 68.9 & 92 \\
Intrapersonal intelligence & 86.8 & 85 \\
\hline
\end{tabular}

The developed/highly developed intelligence profiles of the students were from highest to lowest; musical intelligence $(89.6 \%)$, intrapersonal intelligence $(86.8 \%)$, naturalist intelligence $(80.2 \%)$, bodily-kinesthetic

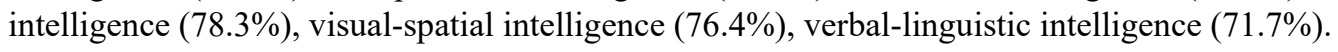

4.2 The Percentage Distribution of other Intelligence Profiles of Students with a Developed/Highly Developed Musical Intelligence

The percentage distribution of other intelligence profiles of students with a developed/highly developed musical intelligence profile is presented in Table 4 .

Table 4. Percentage frequency values of other intelligence profiles of students with a developed/highly developed musical intelligence profile

\begin{tabular}{|c|c|c|c|c|c|c|c|c|c|c|c|c|c|}
\hline \multicolumn{14}{|c|}{ Musical intelligence profile $(\mathrm{n}=95)$} \\
\hline \multicolumn{2}{|c|}{$\begin{array}{c}\text { Verbal-linguistic } \\
\text { intelligence }\end{array}$} & \multicolumn{2}{|c|}{$\begin{array}{l}\text { Logical-mathema } \\
\text { tical intelligence }\end{array}$} & \multicolumn{2}{|c|}{$\begin{array}{l}\text { Spatial-visual } \\
\text { intelligence }\end{array}$} & \multicolumn{2}{|c|}{$\begin{array}{l}\text { Bodily-kinesthe } \\
\text { tic intelligece }\end{array}$} & \multicolumn{2}{|c|}{$\begin{array}{c}\text { Naturalist } \\
\text { intelligence }\end{array}$} & \multicolumn{2}{|c|}{$\begin{array}{c}\text { Inter-personal } \\
\text { intelligence }\end{array}$} & \multicolumn{2}{|c|}{$\begin{array}{c}\text { Intrapersonal } \\
\text { intelligence }\end{array}$} \\
\hline$\%$ & $\mathrm{f}$ & $\%$ & $\mathrm{f}$ & $\%$ & $\mathrm{f}$ & $\%$ & $\mathrm{f}$ & $\%$ & $\mathrm{f}$ & $\%$ & $\mathrm{f}$ & $\%$ & $\mathrm{f}$ \\
\hline 77.8 & 74 & 75.7 & 72 & 83.1 & 79 & 87.4 & 83 & 85.3 & 81 & 71.6 & 68 & 94.7 & 90 \\
\hline
\end{tabular}

The distribution of other intelligence profiles of students with developed/highly developed musical intelligence profile was from highest to lowest as follows; intrapersonal intelligence (94.7\%), bodily-kinesthetic intelligence $(87.4 \%)$, naturalist intelligence $(85.3 \%)$, visual-spatial intelligence $(83.1 \%)$, verbal-linguistic intelligence (77.8\%), mathematical-logical intelligence (75.7\%), and interpersonal intelligence (71.6\%).

\subsection{Comparison of the Multiple Intelligence Profiles According to the Musical Preference of the Students}

The One Way ANOVA test results of the comparisons of the multiple intelligence profiles according to the variable of musical preference are shown in Table 5. 
Table 5. The ANOVA test results of the comparisons of the multiple intelligence profiles according to the variable of musical preference

\begin{tabular}{|c|c|c|c|c|c|c|c|}
\hline Intelligence profile & Groups & $\mathrm{N}$ & $\mathrm{x}$ & ss & $\mathrm{f}$ & Difference between groups & $\mathrm{p}$ \\
\hline Verbal-linguistic intelligence & $\begin{array}{c}\text { Traditional music } \\
\text { Rap/hip-hop music } \\
\text { Classical music } \\
\text { Popular music } \\
\text { Rock/heavy metal } \\
\text { music } \\
\end{array}$ & $\begin{array}{c}46 \\
2 \\
36 \\
19 \\
3\end{array}$ & $\begin{array}{l}33.5 \\
19.0 \\
33.8 \\
34.8 \\
42.3\end{array}$ & $\begin{array}{l}6.0 \\
1.4 \\
5.1 \\
7.1 \\
8.0\end{array}$ & 4.772 & $\begin{array}{c}\text { Classical-Rap/hip-hop } \\
\text { Popular- Rap/hip-hop } \\
\text { Rock/Heavy metal- Rap/hip-hop }\end{array}$ & $.001^{*}$ \\
\hline $\begin{array}{l}\text { Logical-mathematical } \\
\text { intelligence }\end{array}$ & $\begin{array}{c}\text { Traditional music } \\
\text { Rap/hip-hop music } \\
\text { Classical music } \\
\text { Popular music } \\
\text { Rock/heavy metal } \\
\text { music }\end{array}$ & $\begin{array}{c}46 \\
2 \\
36 \\
19 \\
3\end{array}$ & $\begin{array}{l}34.7 \\
20.5 \\
35.3 \\
33.2 \\
31.0\end{array}$ & $\begin{array}{l}5.4 \\
2.1 \\
5.6 \\
7.3 \\
3.6\end{array}$ & 3.505 & $\begin{array}{l}\text { Traditional-Rap/hip-hop } \\
\text { Classical-Rap/hip-hop } \\
\text { Popular- Rap/hip-hop }\end{array}$ & $.010^{*}$ \\
\hline Spatial-visual intelligence & $\begin{array}{c}\text { Traditional music } \\
\text { Rap/hip-hop music } \\
\text { Classical music } \\
\text { Popular music } \\
\text { Rock/heavy metal } \\
\text { music }\end{array}$ & $\begin{array}{c}46 \\
2 \\
36 \\
19 \\
3\end{array}$ & $\begin{array}{l}34.6 \\
19.0 \\
36.0 \\
35.2 \\
42.0\end{array}$ & $\begin{array}{l}6.9 \\
1.4 \\
5.1 \\
5.0 \\
2.0\end{array}$ & 5.025 & $\begin{array}{c}\text { Traditional-Rap/hip-hop } \\
\text { Classical-Rap/hip-hop } \\
\text { Popular- Rap/hip-hop } \\
\text { Rock/Heavy metal- Rap/hip-hop }\end{array}$ & $.001^{*}$ \\
\hline Musical intelligence & $\begin{array}{c}\text { Traditional music } \\
\text { Rap/hip-hop music } \\
\text { Classical music } \\
\text { Popular music } \\
\text { Rock/heavy metal } \\
\text { music }\end{array}$ & $\begin{array}{c}46 \\
2 \\
36 \\
19 \\
3\end{array}$ & $\begin{array}{l}38.9 \\
26.0 \\
40.2 \\
39.1 \\
46.3\end{array}$ & $\begin{array}{l}8.5 \\
4.2 \\
4.6 \\
7.5 \\
5.5\end{array}$ & 2.664 & Rock/Heavy metal- Rap/hip-hop & $.037^{*}$ \\
\hline Bodily-kinesthetic intelligence & $\begin{array}{c}\text { Traditional music } \\
\text { Rap/hip-hop music } \\
\text { Classical music } \\
\text { Popular music } \\
\text { Rock/heavy metal } \\
\text { music }\end{array}$ & $\begin{array}{c}46 \\
2 \\
36 \\
19 \\
3\end{array}$ & $\begin{array}{l}34.3 \\
20.5 \\
34.1 \\
36.8 \\
35.3\end{array}$ & $\begin{array}{l}7.1 \\
0.7 \\
5.6 \\
6.3 \\
2.3\end{array}$ & 3.102 & $\begin{array}{l}\text { Traditional-Rap/hip-hop } \\
\text { Classical-Rap/hip-hop } \\
\text { Popular-Rap/hip-hop }\end{array}$ & $.019^{*}$ \\
\hline Interpersonal intelligence & $\begin{array}{c}\text { Traditional music } \\
\text { Rap/hip-hop music } \\
\text { Classical music } \\
\text { Popular music } \\
\text { Rock/heavy metal } \\
\text { music }\end{array}$ & $\begin{array}{c}46 \\
2 \\
36 \\
19 \\
3\end{array}$ & $\begin{array}{l}32.5 \\
19.0 \\
33.0 \\
36.4 \\
32.3\end{array}$ & $\begin{array}{c}6.1 \\
1.4 \\
5.1 \\
7.1 \\
2.08\end{array}$ & 4.411 & $\begin{array}{l}\text { Traditional-Rap/hip-hop } \\
\text { Classical-Rap/hip-hop } \\
\text { Popular- Rap/hip-hop }\end{array}$ & $.003^{*}$ \\
\hline Intrapersonal intelligence & $\begin{array}{c}\text { Traditional music } \\
\text { Rap/hip-hop music } \\
\text { Classical music } \\
\text { Popular music } \\
\text { Rock/heavy metal } \\
\text { music } \\
\end{array}$ & $\begin{array}{c}46 \\
2 \\
36 \\
19 \\
3\end{array}$ & $\begin{array}{l}35.4 \\
21.5 \\
36.5 \\
37.6 \\
42.0\end{array}$ & $\begin{array}{l}6.2 \\
2.1 \\
3.9 \\
6.9 \\
5.1\end{array}$ & 4.686 & $\begin{array}{c}\text { Traditional-Rap/hip-hop } \\
\text { Classical-Rap/hip-hop } \\
\text { Popular- Rap/hip-hop } \\
\text { Rock/Heavy metal- Rap/Hip-Hop }\end{array}$ & $.002^{*}$ \\
\hline Naturalist intelligence & $\begin{array}{c}\text { Traditional music } \\
\text { Rap/hip-hop music } \\
\text { Classical music } \\
\text { Popular music } \\
\text { Rock/heavy metal } \\
\text { music }\end{array}$ & $\begin{array}{c}46 \\
2 \\
36 \\
19 \\
3\end{array}$ & $\begin{array}{l}36.3 \\
22.5 \\
37.8 \\
36.8 \\
27.6\end{array}$ & $\begin{array}{c}7.9 \\
2.1 \\
5.8 \\
7.4 \\
11.7\end{array}$ & 3.319 & Classical-Rap/hip-hop & $.013^{*}$ \\
\hline
\end{tabular}

$* \mathrm{p}<0.05$.

When the data obtained were analyzed in terms of the musical preference variable, the verbal-linguistic intelligence profile points of students who preferred classical music, popular music, and rock/heavy metal music 
were significantly higher than those of the students who preferred rap/hip-hop music.

The logical-mathematical intelligence, bodily-kinesthetic intelligence, and interpersonal intelligence profile points of students who preferred traditional music, classical music, popular music and rock/heavy metal music were determined to be significantly higher than those of the students who preferred rap/hip-hop music.

The spatial-visual intelligence and intrapersonal intelligence profile points of students who preferred traditional music, classical music, popular music, and rock /heavy metal music were determined to be significantly higher than those of the students who preferred rap/hip-hop music.

A significant difference was determined in the musical intelligence profile points between students who preferred rap/hip-hop music and those who preferred rock/heavy metal music.

The naturalist intelligence profile points of students who preferred classical music were determined to be significantly higher compared to the students who preferred rap/hip-hop music.

\section{Discussion and Conclusion}

Consistent with the findings of several other studies, the results of this study demonstrated that in parallel to the starting point of the Theory of Multiple Intelligences, students have more than one developed intelligence profile. At this point it is extremely important to define an approach within that framework by revealing the other developed intelligence profiles of students with a developed/highly developed musical intelligence profile.

It was observed in this study that the developed/highly developed intelligence profiles of the students were firstly musical intelligence, secondly intrapersonal intelligence and thirdly naturalist intelligence. These were followed by the other intelligence profiles, respectively, as bodily-kinesthetic, visual-spatial, verbal-linguistic and mathematical-logical. This result overlaps with the statement of Brualdi and Amy (1994) that "Everybody is born with 8 intelligences, but unfortunately students come with different sets of developed intelligences" (as cited in Karagüven, 2018). Areas of intelligence always work together, but it is a complex process (Armstrong, 1994). In parallel with that statement by Armstrong, in the evaluation only of students with a developed/highly developed musical intelligence, the other developed intelligence profiles of these students were concluded to be intrapersonal intelligence, bodily-kinesthetic intelligence, naturalist intelligence, visual-spatial intelligence, verbal-linguistic intelligence, mathematical-logical intelligence and interpersonal intelligence, respectively. At this point, it may be thought that everyone is born with these 8 types of intelligence but different intelligence types are used predominantly, and the less dominant intelligence types are used only when necessary. Based on this idea, it can be said that the majority of the predominant intelligence profiles of the trainee music teachers in this study were in the form of communication and worked in combination.

Armstrong (1994) gave the following example to illustrate this point; "For example, a football player uses his bodily-kinesthetic intelligence when running, catching and kicking, visual-spatial intelligence when learning pitch position and task, interpersonal and verbal-linguistic skills when learning rules and discussing and sharing ideas with team mates, and intrapersonal intelligence when evaluating his own performance." If we apply a similar example to one of the most fundamental elements of music education, the skill of playing a musical instrument, then it may be thought that in deciphering the melodic, harmonic, and rhythmic elements of a composition, in addition to musical intelligence, intrapersonal, bodily-kinesthetic, mathematical-logical, and visual-spatial intelligence profiles are used.

In the transfer of these deciphered elements to the keys of the instrument, it can be considered that of the intelligence profiles, the bodily-kinesthetic intelligence profile is used more intensely together with musical intelligence. In the process of shaping the expression and musicality of the work, musical intelligence and intrapersonal intelligence may be regarded as predominant. In parallel with this conclusion, the other dominant intelligence profiles of the trainee music teachers with developed/highly developed musical intelligence were revealed in this study to be intrapersonal and bodily-kinesthetic intelligences. After musical intelligence, bodily-kinesthetic intelligence may be thought of as one of the most important intelligence profiles in learning an instrument, which is one of the fundamental elements of music education. As a result of the experience formed in the brain by the movements made when playing an instrument, motor units are formed related to those movements. As with any other daily function, these experences are gained through repetition. The more frequently these functions are performed the more clearly movement memory specific to the task is formed in the brain (Özel, 2018). The co-ordination of the hands is extremely important. In addition to these complex motor functions, the player possesses combined visual and aural skills, simultaneously converting the visually perceived music symbols into motor commands to be able to perform the piece as necessary (Ayata \& Aşkın, 2008).

Just like bodily kinesthetic intelligence, intrapersonal intelligence can also be considered after musical intelligence 
as one of the most important intelligence profiles on which musical instrument education is based. According to Galamian (2002), "If the player genuinely wants to establish a solid foundation for the sound, he must understand the meaning of the music, have imagination and be able to approach the piece with a personal, emotional and intuitive attitude." (as cited in Özmenteş, 2005).

The fundamental starting point of this study was to determine if the multiple intelligence profiles of students showed differences according to their musical preferences. Thus, by starting from the music genres to which the trainee music teachers listened, and obtaining clues related to which of the intelligence profiles were used predominantly, the clues were consequently important in respect of paving the way for more functional methods. As a general statement, it was concluded from the comparisons in this study that that the multiple intelligence profiles of trainee music teachers differed according to the types of music to which they listened. To the best of our knowledge, there has been no previous study on this subject in the literature.

Finally it was concluded that:

- The verbal-linguistic intelligence profile of students who preferred to listen to classical music, popular music and heavy metal/rock music was more developed than that of students who preferred rap/hip-hop music,

- The logical-mathematical intelligence profiles of students who preferred traditional music, classical music and popular music was more developed than those of students who preferred rap/hip-hop music,

- The spatial-visual intelligence profiles of students who preferred traditional music, classical music, popular music and heavy metal/rock music were more developed than those of students who preferred rap/hip-hop music,

- The musical intelligence profiles of students who preferred heavy metal/rock music were more developed than those of students who preferred rap/hip-hop music,

- The bodily-kinesthetic intelligence profiles of students who preferred traditional music, classical music and popular music were more advanced than those of students who preferred rap/hip-hop music,

- The interpersonal intelligence profiles of students who preferred traditional music, classical music, and popular music were more advanced than those of students who preferred rap/hip-hop music,

- The intrapersonal intelligence profiles of students who preferred traditional music, classical music, popular music, and rock/heavy metal music were more developed than those of students who preferred rap/hip-hop music,

- The naturalistic intelligence profiles of students who preferred classical music were more advanced than those of students who preferred rap/hip-hop music.

The most striking aspect of these results was that all the intelligence profiles of students who preferred rap/hip-hop music were determined to be below the level of development of the muliple intelligence profiles of students who preferred to listen to other types of music. In the comparison of the multiple intelligence profiles, the trainee music teachers who listened to rap/hip-hop music were in greatest contrast to the trainee music teachers who listened to classical music. The verbal-linguistic intelligence, logical-mathematical intelligence, interpersonal intelligence, bodily-kinesthetic intelligence, naturalistic intelligence, intrapersonal intelligence and visual-spatial intelligence profiles of the students who listened to classical music were observed to be more advanced in all cases than those of the students who preferred to listen to rap/hip-hop music.

There is worldwide interest in the Mulitple Intelligence Theory and the 8 intelligence profiles advocated, and attempts are being made to use it in education. When it is considered that to date, importance has only been given to verbal-lingusitic and logical-mathematical intelligence, the idea that individuals displaying other intelligences, based on scientific findings, may be considered 'intelligent' is new. Therefore, every type of intelligence should be given equal value (Talu, 1999). To the question of what the implementation of the Theory of Multiple Intelligence will bring to education, Gardner replies that the aim of this theory is not education, but it provides a powerful tool with which to reach the targets of intelligence areas. If individuals are effectively aware of the areas of strength and weakness of their own intelligence profiles, they will be able to manage and resolve problems encountered in all aspects of life more robustly and productively.

According to the Multiple Intelligence Theory, when people try to make sense of the world around them, of the situations in which they find themselves and the problems they face, they are each equipped with very different thought processes and problem-solving skills. If attention is paid to these differences as the fundamental starting point in the training of music teachers, a way should be found for the most suitable approach to all trainee music teachers and implementation of the most effective methodologies throughout the training process. 
According to Gardner (1999), the aim of the Theory of Multiple Intelligences is to increase academic success by taking a more indivualistic approach to education through the the use of more than one approach to a subject or concept, and the development of an individual's non-dominant abilities. Having information about the multiple intelligence profiles of trainee music teachers allows for characteristics of their dominant intelligence profiles to be used to an advantage in the training process and provides insight into their general character traits. If new approaches based on these characteristics are introduced into the training period, the training will be more robust and more productive. According to Wilson, Multiple intelligence applications ensure a more personal and varied teaching experience for the teacher, providing ease and experience for the evaluation of a student's natural abililty through use of insight and intuition (as cited in Başaran, 2004).

\section{References}

Armstrong, T. (1994). Multiple intelligences in the classroom. Virginia, USA: ASCD Publishing Alexandra.

Ayata, E., \& Aşkın, C. (2008). Müziğin beynin bilişsel fonksiyonlarına olan etkisi. İÜ̈ Dergisi/B Sosyal Bilimler, $5(2), 13-22$.

Aydın, A. (2005). Gelişim ve öğrenme psikolojisi. Ankara: Tekağaç Eylül Yayıncılık.

Azar, A. (2006). Lisede seçilen alan ve öss alan puanları ile çoklu zekâ profilleri arasındaki ilişki. Educational Administration: Theory and Practice, 46, 157-174.

Başaran, I. (2004). Etkili öğrenme ve çoklu zekâ kuramı: bir inceleme. Ege Eğitim Dergisi, 5, 7-15.

Büyüköztürk, Ş., Çakmak, E., Akgün, Ö., Karadeniz, Ş., \& Demirel, F. (2008). Bilimsel araştırma yöntemleri (1st ed.). Ankara: Pegem Akademi.

Çuhadar, C. H. (2017). Müziksel zekâ. Çukurova Üniversitesi, Sosyal Bilimler Enstitüsü Dergisi. 26(3), 1-12.

Demirtaş, H. O., \& Köse, H. S. (2018). Müzik öğretmeni adaylarının müzik türlerine ilgileri üzerine bir inceleme. Abant İzet Baysal Üniversitesi Eğitim Fakültesi Dergisi, 18(3), 1378-1403. https://doi.org/10.17240/aibuefd.2018.18.39790-471128

Gardner, H. (1999). Çoklu zekâ, görü̈smeler ve makaleler. İstanbul: Enka Okulları Yayınları, BZD Yayıncılık.

Gardner, H. (2004). Audiences for the theory of multiple intelligences. Teachers College Record, 106, 212-220. https://doi.org/10.1111/j.1467-9620.2004.00329.x

Geringer, J. M. (1982). Verbal and operant music listening preferences in relationship to age and musical training. Psychology of Music, Special Issue, 47-50.

Hargreaves, D. J., Comber, C., \& Colley, A. (1995). Effects of age, gender, and training on musical preferences of British secondary school students. Journal of Research in Music Education, 43(3), 242-250. https://doi.org/10.2307/3345639

Kaçmaz, D. (2017). Müzik tercihlerine ilişkin kuramsal bir inceleme. İnönü Üniversitesi Sanat ve Tasarım Dergisi, 7(15), 141-152. https://doi.org/10.16950/inustd.320079

Karagüven, M. H. Ü. (2018). Çoklu zekâ teorisi ve eğitimde uygulamaları. Academia Eğitim Araştırmaları Dergisi, 3(2), 1-17.

Karasar, N. (2008). Bilimsel araştırma yöntemi (18th ed.). Ankara: Nobel Yayın Dağıtım.

Kenston, M. J., \& Pinto, I. M. (1955). Possible factors influencing musical preference. Journal of Genetic Psychology, 86, 101-113. https://doi.org/10.1080/00221325.1955.10532899

Köksal, M. S., \& Boran, A. İ. (2015). Üstün yetenekli öğrencilerin IQ puanlarının anne baba eğitimi ve aile geliri değişkenleri açısından karşılaştırılması. Eskişehir Osmangazi Üniversitesi, Sosyal Bilimler Dergisi, 16(1), 109-121. https://doi.org/10.17494/ogusbd.85867

Konecni, V. J. (1982). Social interaction and musical preference. The psychology of music. New York: Academic Press. https://doi.org/10.1016/B978-0-12-213562-0.50021-8

LeBlanc, A., Sims, W. L., Siivola, C., \& Obert, M. (1996). Music style preferences of different age music listeners. Journal of Research in Music Education, 44(1), 49-59. https://doi.org/10.2307/3345413

North, A. C., \& Hargreaves, D. J. (2008). The social and applied psychology of music. New York: Oxford Universty Press. https://doi.org/10.1093/acprof:oso/9780198567424.001.0001

Özden, Y. (2014). Öğrenme ve ögretme. Ankara: Pegem Akademi Yayıncılık.

Özel, Y. (2018). Farklı enstrüman çalan müzisyenlerde vücut farkindalığı ve üst ekstremite fonksiyonlarının 
incelenmesi (Unpublished master thesis). Hasan Kalyoncu Üniversitesi Sağlık Bilimleri Enstitüsü Fizyoterapi ve Rehabilitasyon Anabilim Dal, Gaziantep.

Özmenteş, S. (2005). Müzik eğitiminin boyutları ve çalgı eğitimi. İnönü Üniversitesi Eğitim Fakültesi Dergisi, 6(9), 89-98.

Rentfrow, P. J., \& Gosling, S. D. (2003). The Do Re Mi's of everyday life: the structure and personality correlates of music preferences. Journal of Personality and Social Psychology, 84(6), 1236-1256. https://doi.org/10.1037/0022-3514.84.6.1236

Russell, P. A. (1997). Musical Tastes and Society. In D. J. Hargreaves, \& C. N. Adrian (Eds.), The social psychology of music (pp. 141-158). New York: Oxford University Press.

Şenel, O. (2014). Müzik tercihinin karmaşık arka planı. Uluslararası Sosyal Araştırmalar Dergisi, 7(30), 213-227.

Talu, N. (1999). Çoklu zekâ kuramı ve eğitime yansımaları. Hacettepe Üniversitesi Eğitim Fakültesi Dergisi, 15, 64-72.

Tuğrul, B., \& Duran, E. (2003). Her çocuk başarılı olmak için bir şansa sahiptir: Zekanın çok boyutluluğu çoklu zeka kuramı. Hacettepe Üniversitesi Eğitim Fakültesi Dergisi, 24, 224-233.

\section{Copyrights}

Copyright for this article is retained by the author(s), with first publication rights granted to the journal.

This is an open-access article distributed under the terms and conditions of the Creative Commons Attribution license (http://creativecommons.org/licenses/by/4.0/). 